\title{
PRÁTICA AUTOFICCIONAL: TENTATIVAS DE APREENSÃO DE UM CONCEITO
}

Jacqueline Oliveira Leão*

RESUMO: Este estudo propõe-se a refletir sobre a prática autoficcional, tendo em vista a presença significativa da escrita de si, do eu na literatura contemporânea, do impulso autobiográfico e do recurso à autoficção como estratégia de criação literária Para tal, dar-se-a maior relevo às questões acerca da fabulação, da mobilidade que se aninha no conceito de autoficção, gênero híbrido capaz de "performar" a imagem do eu autoral presente no texto.

PALAVRAS-CHAVE: Autoficção; autobiografia; literatura contemporânea.
* jacleao@hotmail.com

Doutora em Literatura Comparada (UFMG). Pós-Doutora Estudos Literários (UFMG).

ABSTRACT: This study reflects upon the autofictional practice having in mind the significant presence in contemporary literature of self-writing, the autobiographic impulse and the resource to autofiction as a strategy of literary creation. In order to do that focus is placed on issues about, fabulation and the concept of mobility, which includes the notion of autofiction, a hybrid genre that creates a performance of the image of the authorial self present in the text.

KEYWORDS: Autofiction; autobiographic; contemporary literature. 


\section{FICÇÕES E VERDADES AUTOBIOGRÁFICAS}

As memórias, gêneros ou modalidades discursivas, muitas vezes, coextensivas ao sinônimo de autobiografia, pressupõem a ser forma específica de comunicação, com regras e exigências capazes de distingui-las de outros gêneros discursivos. Contudo, se a presença do gênero autobiográfico se vinca ao legado romântico a partir do século XVIII, momento inconteste da elitização do eu, do interesse pela individualidade, como analisar as ficções tomadas por verdades autobiográficas? Como mapear a identidade ou a confissão do eu que escreve, se ele mesmo já encobre uma autêntica ficção na rede bem tramada que é a literatura?

$\mathrm{Na}$ literatura, os modos de encarar o sujeito, compreendendo sua relação com o mundo e com Deus, é uma questão herdeira da visão antropocêntrica do Humanismo, e, na contemporaneidade, vincula-se às teorias sobre o autor, o enunciador e a enunciação. Ao sujeito, segundo a crítica literária tradicional, foi atribuído caráter sagrado, papel de senhor único da matéria narrada, que só se fazia retrato da realidade empírica. $\mathrm{O}$ estruturalismo insurge-se contra esse lugar utópico do sujeito, propondo eliminar e descentralizar a pessoalidade do autor, calcada no prestígio do indivíduo Roland Barthes, por exemplo, em sua Análise estrutural da narrativa, privilegia as funções que os personagens desempenham frente à sequência narrada, afirmando que a questão do sujeito liga-se à noção de personagem e também às suas ações (Cf. BARTHES, 1971: 43).

Além de Barthes, o século XX também encontra, em Michel Foucault (1992), a declaração da "morte do autor" na literatura. Para Foucault, em $O$ que é um autor, a obra, que antes conferia imortalidade ao autor, passou a atestar o seu próprio assassinato. A identidade individual do sujeito que escreve, por intermédio do todo emaranhado entre ele próprio e o escrito, destituiu-se de autonomia formal, fundindo ou esfacelando-se na própria construção do texto, cujos signos criados não refletem mais que a ausência do seu autor (FOUCAULT, 1992:36). Sendo assim, não é isomórfica a relação entre o nome de autor e o nome próprio. O primeiro caracterizaria um modo de ser do discurso, assegurando-lhe uma função classificativa, capaz de descrever, metonimicamente, o conjunto de textos produzidos por alguém e relacioná-los entre si, além de não se confundir com traços tradicionalmente atribuídos às personagens. $\mathrm{O}$ segundo seria apenas um elemento do discurso, agregado ao indivíduo real e exterior que o produziu. O nome de autor "[...] não está situado no estado civil dos homens nem na ficção da obra, mas, sim, na ruptura que instaura um certo grupo de discursos e o seu modo de ser singular". (FOUCAULT, 1992:46).

De outro viés, em Estética da criação verbal, Mikhail Bakhtin afirma que face à criação estética e aos princípios do sentido, 
a relação entre o autor e o personagem deve ser compreendida em função dos próprios elementos constitutivos da obra. Com base na teoria bakhtiniana (Cf. BAKHTIN, 2006:0309), o autor e o personagem são vistos como instâncias que se interpenetram, embora as afirmações feitas pelo autor acerca do personagem não somente vão além, como abrangem as afirmações do personagem sobre si mesmo. No entanto, a posição valorativa, axiológica do autor abarca, além do personagem, o objeto estético no que se refere às formas, à linguagem. Como salienta Bakhtin, é ingênuo pensar-se na voz criativa, na voz do escritor como voz localizada direta. Ela se constrói, na criação estética, sempre de modo deslocado. A voz criativa do autor-criador como elemento estético-formal deve ser entendida não como a voz direta do escritor, mas como ato de apropriação transpassado por uma voz social qualquer, capaz de ordenar o todo estético, de trabalhar a linguagem enquanto permanece fora dessa mesma linguagem.

Contudo, não se podem desprezar as particularidades individuais de que se reveste o autor, porque, se assim podemos dizer, embora este não se configure apenas como resposta aos dados textuais, acentua, pelo gesto de sua própria escrita, cada traço do personagem por meio dos trejeitos, dos gostos, das máscaras, dos sentimentos e dos pensamentos atribuídos a ele. $\mathrm{O}$ personagem criado tem vida autônoma no mundo ficcional, o que de igual maneira se dá com o seu autor, porque o autor, situado para além da obra, é o agente, é a consciência criadora e ativa do todo artístico acabado e do todo do personagem.

O autor, porém, de certo modo, se reveste do personagem, e a relação entre ambos pode, às vezes, apresentar um conjunto teórico semelhante às suas respectivas visões de mundo ou pode representar categorias axiológicas bem distintas daquelas que correspondem à própria existência de um e outro. Dessa forma, insistir apenas em aproximações factuais entre o autor e o personagem ou em explicações de um pelo outro é ignorar a diversidade do todo artístico e a sua especificidade e autonomia.

Por outro lado, se há uma marca axiológica nas escolhas composicionais, a relação entre o autor e o personagem se complexifica mais no texto autobiográfico. Na autobiografia, o personagem se investe de um "autovivenciamento", reclamando sempre novas e novas formas de acabamento, já que ultrapassa, através de sua própria autoconsciência, o limite supostamente colocado pelo autor. No espaço autobiográfico, o personagem é um ser deslizante, autônomo, um eu performático.

Posto isso, na autobiografia, o mais relevante é o nome próprio, a identificação que se faz entre as pessoas do autor 
1. Veja-se que as pesquisas de Philippe Lejeune, em 0 pacto autobiografico, apontam para uma definição de autobiogra retrospectivo que a pesso rea faz de si e de sua própria existência com ênfase em particular, na história de e, em particular, na historia de 2008:49) O texto autobiográfico, 2008.49). O texto autobiográfico, prenta incu assinatura do autor e entrelaça nos fios da memória nos fios da memória, apresenta particular e privado, já que se refere à história de vida do sujeito que a rra A autobiogria que narra. A autobiografia abrange por certo, as escritas intimas de tom memonialistico, documental confessional, has quais o sujeito discursivo se expó ao máximo dentro dos limites do texto, embora ainda seja recriado na perspectiva de seus leitores. e do narrador e, inclusive, entre as pessoas do autor e do personagem, isto é, o sujeito da enunciação e o sujeito do enunciado apresentam a mesma identidade nos mundos interno e externo ao texto. A autobiografia também se configura como narrativa retrospectiva, que trata da vida de determinado indivíduo, distinguindo-se de outras formas discursivas próximas como memórias, biografias, relato pessoal, diário intimo e autorretrato, porque o autor é, ao mesmo tempo, o destinatário e o objeto da escrita.

Então, entendemos que da aliança entre autor, narrador e personagem decorre o pacto autobiográfico ${ }^{1}$. $\mathrm{O}$ acordo feito com o leitor mediante referência explícita ou não no texto indicado como autobiografia. Sendo assim, se a assinatura constante na capa, na contracapa, na orelha e na folha de rosto do livro se identificar ao nome que o narrador se dá como personagem principal, acrescida da indicação ou não da informação de tratar-se de autobiografia, confirmam-se as marcas do pacto autobiográfico entre autor e leitor. Por outro lado, embora ficcional, a biografia do modo como se apresenta, trava um acordo de referencialidade, que, a seu turno, não deixa de ser uma armadilha para o leitor mais ingênuo, para aquele que julga tratar-se do "vivido", desprezando a mediação discursiva. Já o pacto romanesco, presente também na biografia, não se efetiva da mesma forma que no romance explicitamente não biográfico. Neste último, o pacto pretendido muitas vezes visa à negação da identidade do autor e a assunção do caráter ficcional da obra. Acerca dos estudos de Philippe Lejeune, Diana Klinger afirma que

"o que diferencia a ficção da autobiografia não é a relação que existe entre os acontecimentos da vida e sua transcrição no texto, mas o pacto implícito ou explícito que o autor estabelece com o leitor, através de vários indicadores presentes na publicação do texto, que determina o seu modo de leitura. Assim, a consideração de um texto como autobiografia ou ficção é independente do seu grau de elaboração estilística: ela depende de que o pacto estabelecido seja 'ficcional' ou 'referencial'" (KLINGER, 2007:12).

Além disso, se o pacto autobiográfico se relaciona à identidade expressa entre autor, narrador e personagem, não significa que, no jogo discursivo, não haja disparidades na mobilidade do texto, pois o narrador e o personagem podem remeter, simultaneamente, ao autor fora do texto. Do lado do enunciado, o pacto autobiográfico prevê e admite falhas, enganos, esquecimentos e deformações na história do personagem. Além de prever a declaração de princípios, ainda que não os expresse, o pacto procura autenticar o fato narrado com base na realidade referente.
EM TESE
BELO HORIZONTE
v. 20
N. 3
SET.-DEZ. 2014
LEÃO. Prática autoficcional: tentativas de apreensão de um conceito
P. $91-106$ 
Para Costa Lima, em Sociedade e discurso ficcional, todo gênero literário ou não-literário é uma forma de comunicação, que se acerca de regras com o intuito de eliminar equívocos e contradições na interação entre um interlocutor que põe em evidência o processo de leitura, a expectativa do leitor porque, na verdade, quem se propõe a escrever nunca saberá ao certo como será lido, dessa forma, "pensar o estatuto da autobiografia como gênero pressupõe sabermos que o leitor contemporâneo praticamente o reconhece e, embora formalmente não se preocupe ou não saiba defini-lo, conhece seus traços distintivos" (LIMA, 1986:297). É o leitor que se prontifica a diferenciar o eu empírico do eu autobiográfico embaralhado no universo ficcional.

Por outro lado, Costa Lima acrescenta que tomar a autobiografia como confissão da verdade ou caso não o seja como grande fraude, engodo, significa classificá-la documentalmente, isto é, tentar provar de forma suficiente como alguém testemunha ou vive certa experiência, colocando o eu que narra em uma posição constantemente igual, que "vê hoje o seu passado do mesmo modo que o via enquanto passava" (LIMA, 1986:293). Se o eu imaginado é construído nas experiências passadas, a sinceridade é o axioma da autobiografia, mas sabemos que não é o seu ponto estável, início irredutível que se possa apoderar e reverter em palavra. Além disso, a autobiografia não pode ser tomada como documento histórico, pois é apenas o retrato do modo como alguém se vê a si próprio, "de como formulava a crença de que era outro que atendia pelo nome de $e u$ - um outro sem dúvida aparentando ao eu que agora escreve, com reações semelhantes e uma história idêntica, mas sempre um outro a viver sob a ilusão da unidade." (LIMA, 1986:294).

Já no âmbito da estética da recepção, não podemos imaginar mais a autobiografia como gênero rigidamente estruturado. Na verdade, o pacto entre autor e leitor é que legitima a forma de leitura do texto engendrado como autobiográfico, que não apresenta regras explícitas para sua definição, regras para sistematizar-se como tal. Isso quer dizer que é, sobretudo, o modo de leitura que garante as identidades de autor, narrador e personagem, além da relação entre estas instâncias, uma vez que o importante é considerar a autobiografia como forma de leitura e não exclusivamente como forma de escrita, como efetivação de pactos discursivos específicos entre autor e leitor.

Por outro lado, o discurso autobiográfico constituído na Modernidade é o pano de fundo sobre o qual se constrói o discurso da autoficção, que implica em uma nova noção de sujeito, pondo em evidência o retorno da figura do autor depois da crise filosófica do século XIX. Para Diana Klinger, "sustentar a existência de um retorno do autor, implica necessariamente entrar no debate sobre a produção da subjetividade em relação com a escrita”. (KLINGER, 2007:27). Na 
ficção contemporânea, não é mais possível demarcar com exatidão a velha fórmula do estilo individual, do traço inconfundível do tal sujeito da escrita.

Logo, da problematização acerca do autor enquanto instância, afirmação de um eu, de um estilo individual, abre-se uma frente para o leitor que surge, então, como coprodutor de sentidos do texto, estes construídos conforme a maneira própria de sua leitura. Por esse viés, o autor ascende ao status de personagem, o leitor ascende ao status de coautor, sugerindo tudo isso novas articulações de papeis, tornando mais complexa e dinâmica a criação literária, meio constante das reinvenções entre as funções de autor, de texto e de leitor.

\section{AUTOFICÇÃO - TENTATIVA DE APREENSÃO DE UM}

\section{CONCEITO}

Há mais de trinta anos após o surgimento do neologismo autoficção, a crítica ainda não sabe defini-lo em sua inteireza. O termo foi cunhado por Julien Serge Doubrovsky, J.S.D, iniciais que se referem realmente ao autor ao descrever relação entre pai e filho, no [romance?] Fils (1977), baseado em sua própria vida. Vale dizer que, em Fils, Doubrovsky faz referência ao gênero que a obra poderia pertencer, como salienta, não seria uma autobiografia por ser esta um "privilégio" reservado a autores importantes, seria, pois, uma autoficção, ou seja, a ficcionalização de fatos e eventos rigorosamente verdadeiros, escritos em que o nome do personagem principal coincide com o próprio nome do autor.

Claro que Doubrovsky abre outro espaço de percepção do texto autobiográfico, quando, em Fils, apresenta um romance com identidade onomástica entre autor, narrador e personagem, o que, de certa forma, não só preenche a "casa vazia" deixada por Philippe Lejuene em seu "pacto autobiográfico", como também, ao mesmo tempo, antecipa outro tipo de pacto de leitura, pois, embora, em Fils, o nome do autor e do personagem seja o mesmo, é este por último uma construção completamente ficcional, o que destitui o legado tradicional da autobiografia como também do romance.

Nesse sentido, a autoficção é mais que a ficção de fatos e eventos estritamente reais, é também a arte de acomodar os restos do eu no interior da obra através da sintaxe da linguagem, mas escapando das formas do romance tradicional. A autoficção designa a atividade literária de ficcionalização do eu na literatura, já que o eu diz que o que se diz é verdade ou afirma que se mente ao dizer a verdade ou ainda vice-versa, comprovando, por esse gesto, a impossibilidade de transposição da vida para o universo ficcional, embora o autor se transforme em personagem de seu próprio romance, cuja "vida é um livro, um texto, e não há nada no texto que seja autosuficiente.” (DOUBROVSKY, 2002:212). 
Se Doubrovsky tenta definir e se definir dentro da própria obra literária, inspirado no diálogo ou no contraponto das questões abordadas no pacto de Lejeune, para a crítica literária, esses questionamentos se tornaram alvos de muitos estudos, provocando constante debruçar em torno de dois pilares básicos: os postulados de Lejeune, ou seja, o pacto autobiográfico que preconiza a coincidência entre o nome do personagem e o seu autor; e a definição para o conceito de autoficção a partir de Doubrovsky, conceito que, paralelo à autobiografia, é deslizante e híbrido por ser a ficcionalização de si mesmo por parte do escritor.

Como defendido por Doubrovsky, o conceito de autoficção é contraditório ou até mesmo incompatível e só faz sentido quando se pensa na junção de elementos entre a autobiografia e a ficção no movimento de interação do texto. Dessa forma, deve-se levar em conta que escrever a própria autobiografia é, na verdade, tentar contar a própria história de forma original, autêntica, embora com todas as ressalvas resguardadas quanto à transposição do eu no texto por meio da escrita. $\mathrm{Na}$ autobiografia, tenta-se acirradamente conta a história de si da origem até o suporte máximo garantido pela escrita, já, na autoficção, pode-se reduzir a história de si, dando-lhe aspecto bastante diferente, uma intensidade narrativa diferente da história vivida, um aspecto romanceado embora com a presença dos dados factuais.
Se, por um lado, a autoficção institui um eu fictício e, enquanto prática de escrita, não pode ser definida ou categorizada como sendo romance ou autobiografia, pois é, às vezes, um e outro ou nem um e nem outro, esse espaço incerto já propaga a desconstrução do eu, que escorregadio, espelhado, quebra, trinca qualquer certeza, qualquer caráter de estabilidade de si $^{2}$. Por outro lado, a autoficção também semeia o paratexto de experiências conflitantes, lembranças improváveis, escrita ambígua não certificando com propriedade o caráter da ficção, é por isso um trabalho do imaginário em que se incorporam pedaços da vida, mas incorporam também invenções da própria vida, fatos que se multiplicam e se concretizam pela escrita.

\section{AUTOFICÇÃO - ESTILHAÇAMENTOS DE UM CONCEITO}

Muito embora seja certo que, na escrita autoficcional, o autor invente um eu deslizante, eu que está sempre em movimento, tanto no movimento da recriação, da ficcionalização ou da reinvenção de si mesmo, seja certo também que não é possível estatuir qualquer rubrica aos textos autoficcionais ou tentar enquadrá-los sob o aspecto classificativo de qualquer gênero narrativo, pois tal impossibilidade diz respeito a essa essência híbrida da autoficção, que se move entre os dados autobiográficos, ficcionais, memorialísticos no espaço intervalar da própria ficção, ainda assim é importante, para a análise que aqui intentamos, discorrer sobre
2. Cf. DOUBROVSKY, Serge; LECARME, Jacques; LEJEUNE, Philippe: Autofictions et cie. Cahiers RITM: Université de Paris $X, n^{\circ} 6,1993$, p. 81-83. 
os estilhaçamentos do conceito de autoficção [modelo de Doubrovsky], proposto por Vincent Colonna (2004).

De acordo com os estudos de Vincent Colonna, ficcionalizar o eu é criar um sujeito imaginário, sujeito que conta uma história, contribuindo e colaborando com a fabulação de si, pois passa a ser, ele próprio, o elemento de sua própria invenção. Nesse sentido, na literatura autoficcional, o autor e o personagem se vinculam a partir de uma identidade nominal que com partilha a obra de ficção, embora uma mesma obra possa ser determinada pela coexistência de diferentes posturas e práticas autoficcionais. De maneira didática, talvez, Vincent Colonna (2004) traçou quatro tipologias, posturas ou tendências de criação autoficcional que podem ser assim compreendidas:

A primeira delas é nomeada de Autoficção Fantástica. Nessa prática de escrita, (Cf. COLONNA, 2004:75), o protagonista tem o nome do autor, o primeiro se identifica com o segundo como na autobiografia, mas o duplo fictício, por meio do próprio elemento fantástico, é ficção total, uma fabulação, uma invenção inconfundível, que se encontra para muito além da identidade do autor na realidade referente. Por outro lado, a figura do eu autoral permeia toda a história, sendo, embora de forma fantasiosa e inverossímil, o centro da narrativa, mas, ressalte-se que o duplo fictício, caracterizado pela própria ficção, não imita a existência [mundo referente] do autor empírico, se inventa na ficção, na irrealidade em que aquele se inscreve.
Dessa forma, podemos acrescentar que, nessa tendência de criação defendida por Vincent Colonna, a correlação entre fato e ficção é quase nula e a existência e a identidade são instâncias também quase nulas, pois o duplo projetado na narrativa se torna um personagem incomum, totalmente ficcional, que se situa além da vida e da escritura. Além disso, a Autoficção Fantástica sugere que o foco de escrita não seja a existência do autor, mas o processo de criação que envolve os desvios e as surpresas entre a ficção e a biografia autoral, já que o mais importante é a ficção em si, ficção que, inclusive, paradoxalmente, só faz contrastar o duplo papel do autor: ser, ao mesmo tempo, o sujeito responsável e o sujeito sujeitado [pela/à] própria criação narrativa.

Já a segunda tipologia é a Autofiç̧ão Biográfica, escrita que mais se aproxima do modelo doubrovskiano de autoficção por mesclar dados, fatos históricos, nomes ficcionais a situações factuais, distinguíveis na realidade referente. Nesse sentido, é possível perceber algumas nuances entre a história organizada e a existência empírica do autor que fabula a si mesmo a partir de dados factuais e cria, paradoxalmente, um núcleo narrativo tido por verdadeiro, sustentado pelos créditos das “verdades literárias”. (Cf. COLONNA, 2004:93)

A nosso ver, daí decorre que, na Autoficção Biográfica, o autor, ao se projetar no texto, tende a se unificar em torno de si mesmo, em torno da ideia, da imagem proposta 
literariamente, já que assume a própria história em concordância com o narrador, o personagem principal, o seu homônimo, que é o espelho não só de sua vida como também de seu relato. Além disso, o autor, no papel de protagonista, reivindica "verdades literárias", ou seja, ao afirmar datas, fatos, nomes, sem dúvidas, distorce a realidade empírica, mas constrói uma ficção ao redor de um eixo central cujos esboços são aceitos por verdadeiros. Vale dizer ainda que, se a realidade referente é recriada através das possibilidades ofertadas pelo autor, este liberto de suas amarras cotidianas, passa a legislar sobre o texto, ou seja, continua presente no plano textual através da imagem modelada de si mesmo, das fabulações dos dados factuais, fabulações que se relacionam com a verdade referente, mas que são, em todo caso, verdades inventadas.

$\mathrm{Na}$ terceira tipologia, a Autoficção Especular, o realismo do texto é fator secundário, pois o autor aparece na história por meio de uma performance, estando mascarado, sombreado sendo, sobretudo, um personagem enviesado, multiplicado pelo jogo da mise-en-abyme. Vincent Colonna (2004:119), afirma que, na Autofiç̧ão Especular, o autor, por não ser mais o centro da narrativa, inclui-se nela por meio de personagen autores, cuja atividade criadora do autor empírico aparece refletida no fazer literário do autor na ficção. Nesse sentido, a verossimilhança decorre da presença do autor incluído no texto, ou seja, o duplo fictício, o autor do autor da narrativa, reflete ao mesmo tempo sobre o processo ficcional e sobre o autor criado na própria ficção, tal qual o "reflexo da metáfora do espelho", em que o personagem se identifica com o autor através de seu próprio reflexo na obra. A Autofiç̧ão Especular põe em questão o fazer autoral, as suas influências intertextuais e a sua recepção, deixando, sobretudo, o reflexo do autor na própria ficção, ficção em que o personagem não somente se identifica com o autor, mas, através dele, se configura, tornando-se fundamental no texto.

A quarta e última tipologia denomina-se Autofiç̧ão Intrusiva ou Autoral. Nessa prática de escrita, o autor-narrador não é um personagem central da ação, ele é a voz solitária e sem corpo, paralela à história e associado ao escritor Para Vincent Colonna (2004:135), o autor representado é um narrador, um comentador, um breve "autor-narrador", um "contador de histórias" à margem da trama, que oculta o mecanismo de ato da ficção, mas contamina o autor, convertendo-o em outro em si, si que é uma transformação do escritor, escritor, por sua vez, que não se realiza através de um personagem e não pertence à história em si.

\section{AUTOFICÇÃO - OUTRAS PERSPECTIVAS TEÓRICAS}

A ficcionalização da experiência vivida pelo autor, em seu próprio texto, somente certifica a autoficção como estratégia 
de ficcionalização do eu na narrativa, uma encenação do autor misturando-o [e ou mesmo rompendo] com a linha divisória que se conjuga com a realidade empírica e a ficcionalizada, esfumaçando aquilo que é ficcional e factual, o que, por outro lado, constrói a figura do autor, pondo em cena o seu desaparecimento e, paradoxalmente, encena o seu ressurgimento a partir do procedimento de escrita chamado autoficção. Nesse sentido, "ficcionalizar os dados significa considerá-los como metáforas, ordená-los de modo narrativo, sem que haja qualquer desvio em relação à "verdade factual” (SOUZA, 2011:11)

Além disso, para Eneida Maria de Souza (2011), a realidade e a ficção são instâncias totalmente indissociáveis, pois não se opõem de forma radical, o que significa dizer que não é prudente, ou também satisfatória à análise literária verificar, em se tratando de biografia ou autobiografia, se o acontecimento é verídico ou não, tendo em vista que o "próprio acontecimento vivido pelo autor - ou lembrado, imaginado - é incapaz de atingir o nível de escrita se não são processados o mínimo distanciamento e o máximo de invenção" (SOUZA, 2011:21).

Há de se entender que não se trata de reduzir a obra à vivência do autor, demonstrando se a ficção é fruto ou resultado de sua experiência pessoal e única. A escrita autoficcional, por certo, funde fato e ficção, mas, por outro lado, deixa sempre garantida a incapacidade de o sujeito se mostrar, se revelar, se expor por inteiro através da escrita. A ficcionalização do eu é, na verdade, o próprio encenamento do eu, encenamento de sua subjetividade no ato da escrita e do discurso, pois o dado narrado no texto é, sobretudo, uma reinvenção do vivido, embora ainda que esta se paute pela fidelidade às normas dos acontecimentos, há de se afirmar sempre uma construção literária.

O discurso autobiográfico fundido ao discurso ficciona relativiza ambos, pois admite outras possibilidades de representação do escritor e, ao mesmo tempo, oferece outro viés de percepção do objeto literário, que se torna híbrido e diferenciado, pois não se pode falar em fronteiras delimitadas do discurso autobiográfico e ficcional. Se Doubrovsky, em 1977, cunhou o conceito de autoficção, Colonna o reconfigurou como gênero híbrido, em que a ficcionalização do eu se torna para os mais variados grupos de autores uma prática literária pautada pela escrita das aparências. A autoficção confere à ficção o estatuto do vivido, jogando com a verdade através de um sujeito metamorfoseado, ambiguamente fortalecido pelo pronome eu, que figura entre o factual e fictício. O que desconstrói o limite rígido entre a autobiografia e a trama potencialmente engendrada no texto literário, porque "a trama literária tem a liberdade de engendrar autobiografias falsas" (SOUZA, 2011:72).

Por outro lado, conforme Silviano Santiago (2008), na composição literária, no jogo autoficcional, o autor pode se alicerçar nos dados autobiográficos, vistos como "força motora" da criação no momento em que idealiza e compõe os 
seus escritos e, eventualmente, pode por eles ser explicado, jogando por terra a expressão meramente confessional, porque o próprio autor põe em cena a subjetividade criadora e os fatos da realidade. Nesse sentido, o que conta no processo criativo é o discurso marginal em constante contaminação, o texto híbrido, a contaminação da autobiografia pela ficção e da ficção pela autobiografia, porque ao trabalho do escritor e à escrita criativa inserir [...]

alguma coisa (o discurso autobiográfico) noutra diferente (o discurso ficcional) significa relativizar o poder e os limites de ambas, e significa também admitir outras perspectivas de trabalho para o escritor e oferecer-lhe outras facetas de percepção do objeto literário, que se tornou diferenciado e híbrido. Não contam mais as respectivas purezas centralizadoras da autobiografia e da ficção; são os processos de hibridização do autobiográfico pelo ficcional, e vice-versa, que contam. (SANTIAGO, 2008:174).

Além disso, na visão de Evando Nascimento (2010:195), a autoficção não se apresenta com características definidas como o gênero autobiográfico [que se constitui no eu criado através do registro do outro, do outro que se diz dizer a verdade] e tentar enquadrá-la em qualquer classificação, mesmo que provisória, soa como traição à criação literária, ao "impulso inventivo", pois, em muitos casos, o atestado de verdade do texto é justamente aquele que já o certifica como verdade ficcional através do ato performativo do discurso. Vale dizer que a autoficção não se limita, não legitima nenhum gênero, não se compromete nem mais ou menos nem com o factual e, muito igualmente, nem com o ficcional, simultaneamente, hibridiza o real, o imaginário, a ficcionalidade, a referencialidade na própria incerteza discursiva, na incerteza daquilo que se afirma como sendo o mundo referente, mas que é o tempo todo apenas o que o representa como se fosse o que parece ser.

Então, se o discurso preserva as marcas factuais quanto ficcionais do sujeito que o produziu através de uma hibridização perturbadora, a autoficção deve ser compreendida dentro de uma performance discursiva e não sob a ótica ontológica/convencional dos vários gêneros, pois os textos autoficcionais rompem as barreiras entre o "literário" e o "literal" e, ao fazer coincidir "os nomes e as biografias do autor, do narrador e do protagonista, o valor operatório da autoficção cria um impasse entre o sentido literal (a referência real da narrativa) e o sentido literário (a referência imaginária)". (NASCIMENTO, 2010:196-197).

\section{CONSIDERAÇÕES FINAIS - ÚLTIMAS PALAVRAS}

\section{OEICCÁ}

A autoficção não se constitui gênero específico, embora seu estudo esteja emergente, sendo, inclusive, uma tendência 
crescente na crítica contemporânea. Por outro lado, os textos que parecem conter os dados biográficos do autor têm sido nomeados indiscriminadamente por autoficcionais. Disso decorre que se, em dado texto ficcional, o personagem principal tem o mesmo nome do autor, o leitor depara-se com "autoficção"; se há semelhança entre aspectos familiares e pessoais, "autoficção", o que não faz muito sentido à análise crítica. Obviamente, o termo autoficção carrega em si uma classificação ambígua, e, ainda que haja o pacto ficcional que transcenda o pacto autobiográfico entre a vida do autor e a fidelidade do narrado, tais elementos podem fazer referência à realidade, mas não devem ser o centro de referência da leitura que, na verdade, é o conjunto de interação entre o texto, o leitor e o autor.

Embora sendo muito controverso, o conceito, autoficção, se acerca do gênero híbrido, da reinvenção na escrita, do movimento dúbio entre a ficção e o espaço ambíguo da autobiografia. A autoficção aproxima-se, de forma sinonímica, do romance autobiográfico ou da autobiografia ficcional pois é a própria ficção de acontecimentos reais, a subversão da escrita introspectiva, das fabulações de si. Vale dizer, inclusive, que as imersões ao mundo imaginário juntamente com as apropriações das experiências factuais, ocorrências próprias do constructo ficcional, são estratégias escriturais que possibilitam o esfacelamento do eu, seja o eu textual, ou o eu autoral, ou o eu fictício, ou o eu empírico em vários sujeitos enunciativos, configurando-se um atentado contra o gênero autobiográfico canônico, aquele proposto por Philippe Lejeune, em $O$ pacto autobiográfico.

Nesse sentido, na autoficção, há misturas de gêneros e formas discursivas, já que se busca resgatar e recompor os resquícios do vivido, dos fatos verdadeiros, da memória do próprio sujeito, recompor afinal uma nova percepção de si mesmo, do sujeito fragmentado, através da imagem criada do outro eu fictício. Por outro lado, se a autobiografia se propõe a contar a história de vida, desde o princípio, a história de quem a escreve, a autoficção é, por si só, a ficcionalização da escrita do eu, é a própria escrita que se permite ao recorte subjetivo da história real vivida, é a escrita que se reinventa a partir das perspectivas e escolhas do eu criado na realidade ficcional.

Além disso, a autoficção é sempre uma representação, um recontar da própria vida que é uma construção narrativa, uma história contada pelo sujeito a partir da própria rememoração: vida e sujeito como "seres de papel", construídos nos atos de escrita e leitura. A autoficção não somente problematiza, mas, ao mesmo tempo, rompe com a rigidez do binarismo entre fato e ficção, pois a escrita autoficcional não pretende ser o retrato da realidade referente, mas sim a forma articuladora de eventos reais, eventos armazenados na memória e representados no texto por meio de elementos 
ficcionais e auto-referenciais, isto é, o jogo literário focado em dupla [e paradoxal] perspectiva: a factual e a fictícia.

Se pensarmos nas abordagens de Doubrovsky e Colonna, podemos tomar como ponto de intercesão que a autoficçao apóia e, ao mesmo tempo, configura a obra como ficcional, pois o autor, sim, ao recorrer aos dados de sua vida, a algum episódio em específico, os altera por questões pessoais ou estéticas, mas, sem dúvida, esse mesmo autor não somente dá corpo a um personagem que o representa na ficção, como também evidencia a própria presença dentro da obra. Vale dizer, pois, que, ao explorar o vinco factual e ficcional no texto autoficcional, o autor se ficcionaliza atrás de personagens e situações imaginárias, reforçando o caráter de ficção da obra, tornando-se a si mesmo ainda mais indefinido impessoal. Logo, se a autoficção é uma estratégia criativa do autor para marcar a sua presença na ficção, não se pode dizer que em uma determinada obra as posturas ou práticas autoficcionais estejam definidas, ao contrário, estão fundidas, pois se constituem como marcas discursivas, evidenciadas pela escrita.

De outra forma, podemos entender ainda que a autoficção se configura por ser aquela prática de escrita em que o autor e o personagem se fundem, extrapolando as fronteiras do que se convencionou a chamar factual e fictício, aliás, estas instâncias se confundem na própria confusão das identidades do autor e do personagem. Por outro lado, há de se considerar que o pacto de leitura sugerido frente da obra autoficcional é aquele que pressupõe as possibilidades ficcionais experimentadas pelo autor dentro da própria ficção, ou seja, a ficcionalização de si mesmo pelo próprio autor. Nesse sentido, a obra que se firma sob o estatuto da autoficcionalidade reafirma o seu caráter híbrido de pacto com o leitor, tensionando a autobiografia com o caráter romanesco do texto produzido, pois a autoficção, sobretudo, traz à tona a construção da autoria que, por outro viés, também provoca discussões acerca da recepção textual no contexto contemporâneo.

Dessa forma, a autoficção problematiza os personagens da ficção de forma dicotômica. Primeiro, há de se entender que o autor, através de seu autoengendramento, recria a si mesmo, vinculando-se ao personagem construído na ficção. Segundo, o autor, como espectador de sua imagem projetada na narrativa, abre-se em possibilidades literárias de hibridizar fato e ficção, de forma simples ou combinada, sendo, por esse fato, outro, um duplo com natureza fictícia, outro que habita o mundo da ficção e que se mantém apoiado, paradoxalmente, pela realidade referencial, por meio daquele que o reflete. Se entendida assim, logo a autoficção é uma construção narrativa proposta pelo pacto de autenticidade identitária do autor, mas é sempre uma criação literária, atestada pelo caráter de ficção do próprio fazer literário. 
O autor, na autoficção, embora esteja apagado biograficamente, constrói-se nas brechas de sua própria escrita de contar de si mesmo, como eu produzido no texto. Ora, se o objeto literário é sempre resignificado, a autoficção, paralela à escrita autobiográfica, pode ser vista como procedimento literário que, além de hibridizar as fronteiras entre o factual e o fictício, traz à cena aporias que possibilitam o ressurgimento da figura autoral, ou seja, na autoficção, o autor se legitima nos textos e se representa através do escrito ou representa aquele que intenta dizer, pois não se constitui como instância explicativa dos textos, mas como possibilidade perfomática [dessubjetivação] de sua própria imagem imagem, esta, encenada nos textos autoficcionais. Nesse sentido, o autor aparece borrado, investido da impossibilidade de confirmar o dado narrado como verdade ou não, sendo, ao mesmo tempo, uma figuração de si, uma visibilidade transparente, porque o próprio contar de si, seja este contar reminiscente ou não, já é fiç̧ão.

Por outro lado, como já dissemos, a autoficção não é um conceito inovador, já que muitos escritores do passado recorreram ao fingimento de sua biografia na ficção, o que decorre na dificuldade de categorizar a autoficção como gênero. Dessa forma, o autor supera o paradigma da morte do sujeito, da dessubjetivação do eu, para se investir no jogo de sua representação, ainda que esse jogo seja uma performance configurada no texto, uma figuração como qualquer outra.
Então, meio a essa performance de multiplicidades autorais, embora estrategicamente seja garantida pela instabilidade do eu, o autor está calçado em um substrato referencial externo ao texto, um eu autor, um autor consciente de sua não-morte no texto, porque a autoficção legitima a injunção híbrida do eu ficcional com o eu referencial.

$\mathrm{Na}$ autoficção, estabelecem-se fronteiras discursivas entre o eu e o eu imaginado, pois alarga a expressão do eu referencial, duplamente considerado ficção. O eu referencial [autor empírico] e a construção de si [a sua figura que, embora ficcional garante a sua presença no texto]. Então, o autor declarado anteriormente morto, ressurge assumindo um duplo estatuto: o eu dessubjetivado, vazio, em que se insere a escrita no texto e, paradoxalmente, o autor como enunciador, embaralhado no universo ficcional, recriado na escritura, já que, na autoficçao, se intenta a reafirmar a própria figura de si, a própria posição do autor, que finge, dentro do texto, ser outros atrás das marcas ficcionais. Nesse sentido, a construção ficcional alude aos dados que se contemplam na relação intersubjetiva com o leitor, levando à contínua espiral de perguntas: isso se trata de uma ficção ou de uma autobiografia. Ou de uma autoficção, embora o autor intente a escrever uma ficção? Como responder a tal pergunta, se o autor, muitas vezes, é tomado em seu estatuto ontológico de personagem, o eu fictício é tomado por real, e o real ficcional é vicariamente dado por real? 


\section{REFERÊNCIAS}

AZEVEDO, Luciene Almeida de. Autoficção e literatura contemporânea. In: Revista Brasileira de Literatura Comparada, São Paulo, n. 12, p. 31-49, 2008

BAKHTIN, Mikhail. Estética da criação verbal. Trad. Paulo Bezerra. São Paulo: Martins Fontes, 2006

Barthes, Roland. Introdução à análise estrutural da narrativa. In BARTHES, et al. Análise estrutural da narrativa. Trad. Maria Zélia Barbosa Pinto. Petrópolis: Vozes, 1971.

BARTHES, Roland. Roland Barthes por Roland Barthes. São Paulo: Estação Liberdade, 2003

CARNEIRO, Flávio Martins. No país do presente: ficção brasileira no início do século XXI. Rio de Janeiro: Rocco, 2005.

CERTEAU, Michel de. A escrita da história. Trad. Maria de Lourdes Menezes. Rio de Janeiro: Forense Universitária, 2000.

COLONNA, Vincent. Autofictions \& autres mythomanies littèraires. Tristram, París, 2004

COLONNA, Vincent. L'autofiction (essai sur la fictionalisation de soi en literature). Doctorat de I' Ecole des Hautes Etudes em Sciences Sociales, Paris, 1989.

COLONNA, Vincent. Note sur une autofiction fantastique (Comment j'ai cru écrire Ma vie transformiste). In: JEANNELE, Jean-Louis ; VIOLLET, Catherine (Dir). Genèse et autofiction. Belgique: Academia AB-Bruylant, 2007. v.6.p.177-184.
DOUBROVSKY, Serge. Les points sur les « $i$ i. In: Genèse et autofiction. In: JEANNELE, Jean-Louis ; VIOLLET, Catherine (Dir). Academia AB-Bruylant. Belgique, v.6, 2007.p.53-55.

DOUBROVSKY, Serge: Un amour de soi. Paris, Galilée, 1982

DOUBROVSKY, Serge; LECARME, Jacques; LEJEUNE, Philippe: Autofictions et cie. Cahiers RITM: Université de Paris $X, n^{\circ} 6$, 1993, p. 81.

DOUBROVSKY, Serge. Fils. Paris, Galilée, 1977

DOUBROVSKY, Serge. Écriture de soi et lecture de l'autre.

Dijon: Éditions Universitaires de Dijon, 2002, p. 212.

FIGUEIREDO, Vera Lúcia Follain de. Os crimes do texto: Rubem Fonseca e a ficção contemporânea. Belo Horizonte: Ed. UFMG, 2003

FONSECA, Rubem. José. Rio de Janeiro: Nova Fronteira, 2011.

FOUCAULT, Michel. O que é um autor? 2ed. Lisboa: Veja, 1992.

FOUCAULT, Michel. As palavras e as coisas: uma arqueologia das ciências humanas. Trad. Salma Tannus Muchail. 8. ed. São Paulo: Martins Fontes, 1999.

GALLE, Helmut. Elementos para uma nova abordagem da escritura autobiográfica. In: Matraga: Revista do Programa em Pós-Graduação em Letras/Universidade do Estado do Rio de Janeiro: UERJ, ano 13, n. 18, jan-jun. 2006.

KLINGER, Diana. Escritas de si, escritas do outro: o retorno do autor e a virada etnográfica. Rio de Janeiro: 7 Letras, 2007. 
LEÃO, Jacqueline Oliveira; CURY, Maria Zilda Ferreira. A escrita autoficcional do Diário do sedutor, de Søren Kierkegaard. In: ALMEIDA, Jorge Miranda de; LIMA, Fransmar Costa

(ORGS.). Subjetividade, filosofia e cultura. São Paulo: LiberArs, 2011.

LEÃO, Jacqueline Oliveira. Sérgio Kokis: autoficção, memória e imaginário. In: LEÃO, Jacqueline Oliveira; MARTINS, Jasson da Silva; BITTENCOURT, Renato Nunes (Orgs.). Filosofia, cinema e literatura: intercessões. São Paulo: LiberArs, 2011.

LEJEUNE, Philippe. $\mathbf{O}$ pacto autobiográfico: de Rousseau à internet. Belo Horizonte: Ed. UFMG, 2008.

LIMA, Luiz Costa. Júbilos e misérias do pequeno eu. In: Sociedade e discurso ficcional. Rio de Janeiro: Guanabara, 1986, p. 243-309

NASCIMENTO, Evando. Matérias-primas: da autoficção à

autoficção - ou vice-versa. In: NASCIF, Rose Mary Abrão; LAGE,

Verônica Lucy Coutinho (Orgs.). Literatura, crítica, cultura IV :

interdisciplinaridade. Juiz de Fora: UFJF, 2010.

PIGLIA, Ricardo. O último leitor. São Paulo: Companhia das Letras, 2006.

ROCHA, João Cezar de Castro (Org.). Teoria da ficção:

indagações à obra de Wolfgang Iser. Rio de Janeiro: Eduerj,

1999.

SANTIAGO, Silviano. Meditação sobre o ofício de criar. In:

Revista Aletria, Belo Horizonte, n. 18, p. 178, jul./dez. 2008.
SINGER, Isaac Amor e exílio. Trad Lya Luft Porto Alegre: LPM 2005

SOUZA, Eneida Maria de. Janelas indiscretas: ensaios de crítica biográfica. Belo Horizonte: Editora UFMG, 2011 